\title{
Fluorescence in situ hybridization method using a peptide nucleic acid probe for identification of Lactobacillus spp. in milk samples
}

\author{
Antonio Machado a , Carina Almeida ${ }^{\mathrm{a}}$, Ana Carvalho ${ }^{\mathrm{a}}$, Filip Boyen ${ }^{\mathrm{b}}$, Freddy Haesebrouck ${ }^{\mathrm{b}}$, Ligia Rodrigues ${ }^{\mathrm{a}}$, \\ Nuno Cerca ${ }^{\mathrm{a}, *}$, Nuno Filipe Azevedo ${ }^{\mathrm{c}}$ \\ a IBB-Institute for Biotechnology and Bioengineering, Centre of Biological Engineering, University of Minho, Campus de Gualtar 4710-057, Braga, Portugal \\ ${ }^{\mathrm{b}}$ Laboratory of Veterinary Bacteriology and Mycology, Faculty of Veterinary Medicine, Ghent University, B9820 Merelbeke, Belgium

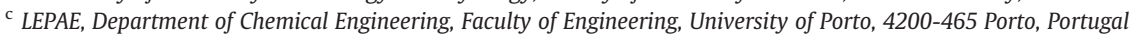

\section{A R T I C L E I N F O}

\section{Article history}

Received 17 April 2012

Received in revised form 11 September 2012

Accepted 30 September 2012

Available online 9 January 2013

\section{Keywords:}

Fluorescence in situ hybridization (FISH)

Peptide nucleic acid probe (PNA probe)

Lactobacillus spp.

Food biotechnology

\begin{abstract}
A B S T R A C T
Lactobacillus species constitute one of the dominant and beneficial bacteria in our body and are used in developed countries as a microbial adjuvant. Identification of these probiotic bacteria is traditionally performed by culture-based techniques. However, such methods are very time-consuming and can give inaccurate results, especially when Lactobacillus is present in mixed bacterial complex communities. Our study aimed to accurately identify Lactobacillus spp. using a novel Peptide Nucleic Acid (PNA) Fluorescence In Situ Hybridization (FISH) probe. The probe (Lac663) was tested on 36 strains belonging to different Lactobacillus species and on 20 strains of other bacterial species. The sensitivity and specificity of the method were 100\% (95\% confidence interval (CI), 88.0 to $100.0 \%$ ) and $95.0 \%$ (95\% CI, 73.1 to 99.7\%), respectively. Additionally, we tested the applicability of the method on milk samples added with Lactobacillus strains at probiotic range concentrations and other taxonomically related bacteria, as well as pathogenic bacteria. The Lac663 probe bound exclusively to Lactobacillus strains and the described PNA-FISH method was capable of directly quantifying Lactobacillus spp. in concentrations at which these potential probiotic bacteria are considered to have an effective benefit on human health.
\end{abstract}

(c) 2012 Elsevier B.V. All rights reserved.

\section{Introduction}

Probiotics are live microorganisms that, when administered in adequate amounts, confer a health benefit to the host (Gaurner et al., 2008). The addition of probiotics to enhance the nutritive value and potential health benefits of foods is now a matter of great interest. Among the most used organisms are those belonging to the genus Lactobacillus, which are believed to have beneficial effects on human health (Matsumoto et al., 2006; Saxelin et al., 2005). However, there is no consensus regarding the minimum number of probiotic bacteria that need to be consumed to produce a beneficial effect (Farnworth, 2008; Gaurner et al., 2008). The Fermented Milks and Lactic Acid Bacteria Beverages Association of Japan has set a minimum of $10^{7}$ bacteria/g or ml (Ishibashi and Shimamura, 1993). Considering that each dose should not have more than $100 \mathrm{ml}$, the concentration should not be lower than $10^{7} \mathrm{CFU} / \mathrm{ml}$ (FAO/WHO, 2006; LourensHattingh and Viljoen, 2002).

The Lactobacillus genus is a heterogeneous group with more than 100 species and subspecies, many of them used as probiotics, silage inoculants and as starters in fermented food in industrial technology. Nevertheless, a wide range of important strains remain to be discovered

\footnotetext{
* Corresponding author.

E-mail address: nunocerca@ceb.uminho.pt (N. Cerca).
}

and characterized which may be used in food and feed biotechnology applications (Giraffa et al., 2010; Matsumoto et al., 2006). Currently, there is a great need to improve the experimental detection of Lactobacillus species, thus the design of screening methods for these microorganisms is still under development (Satokari et al., 2003).

In food microbiology, the choice of an appropriate technique to study microbial communities depends on the aims of the research, the complexity of the community and the required resolution and sensitivity level. Identification is traditionally performed by culturebased techniques, but molecular methods are able to detect noncultivable microorganisms, providing a more comprehensive picture of the total community (Bernardeau et al., 2008). One of the most disseminated methods for bacterial community analysis is based on the extraction of the total community DNA, followed by PCR amplification of the nucleotide sequence of interest (Spiegelman et al., 2005). Nevertheless, the presence of numerous usual compounds such as polysaccharides, carbohydrates, proteins or even salts may hamper DNA extraction and affect PCR efficiency during the amplification stages (Mothershed and Whitney, 2006).

Fluorescence In Situ Hybridization (FISH) is another technique used for bacterial identification, which combines the simplicity of microscopy observation and the specificity of DNA/rRNA hybridization. This methodology is based on the hybridization of labeled DNA probes to taxon-specific regions of the bacterial ribosomes (16S and 
23S rRNA sequences), that are usually detected by fluorescence microscopy. In addition, the FISH procedure can be accomplished in a few hours, allowing fast in situ analysis (Amann and Fuchs, 2008; Justé et al., 2008). After Langer-Safer et al. (1982) developed FISH, this technique has been used to detect and quantify the presence or absence of specific DNA/rRNA sequences. FISH fluorescent probes show a high degree of specificity to complementary sequences and therefore have been applied in numerous fields of research. In the specific context of food technology, FISH has been also applied for the detection of specific lactic acid bacteria (LAB) in natural whey cultures for the production of hard cooked cheeses, a matrix which is very similar to fermented milks (Bottari et al., 2010; Matte-Taillez et al., 2001), in wine (Sohier and Lonvaud-Funel, 1998) and for probiotic bifidobacteria quantification in fermented food (Kaufmann et al., 1997; Lahtinen et al., 2005; Shah and Lankaputhra, 1997; Tabasco et al., 2007). Moreover, FISH is well established as an advantageous method for cultivation-independent detection of microorganisms in many different sample types.

However, DNA probes frequently showed low fluorescent responses in hybridized samples due to numerous factors, such as, low ribosome content of cells, difficult cell wall permeabilization and the presence of rRNA secondary and tertiary structures (Justé et al., 2008). Consequently, peptide nucleic acid (PNA) probes have emerged as an alternative to DNA probes as a more efficient molecular method for rapid microbial detection (Stender et al., 2002). PNAs recognize and bind to their complementary nucleic acid sequences with higher thermal stability and specificity than the corresponding deoxyribooligonucleotides. PNA probes targeting specific $16 \mathrm{~S}$ and $23 \mathrm{~S}$ rRNA sequences of bacteria with clinical, industrial and environmental relevance have been successfully described by several researchers (Almeida et al., 2009, 2010; Guimaraes et al., 2007; Matte-Taillez et al., 2001).

Our main goal consisted in the design, characterization and evaluation of a new fluorescently labeled PNA probe for the specific detection of the Lactobacillus genus by FISH. To validate our probe, we determined its specificity and sensitivity against a great variety of Lactobacillus strains and other related bacterial strains. Subsequently, the PNA FISH method was evaluated on fresh milk samples to which lactobacilli were supplemented in concentrations found in several products after probiotic fermentation.

\section{Materials and methods}

\subsection{Culture of bacterial strains}

The bacterial strains used in this study are listed in Table 1. All strains were maintained on Brain Heart Infusion agar (BHI; Oxoid, United Kingdom) or de Man, Rogosa and Sharpe agar (MRS; Sigma, Portugal) at $37{ }^{\circ} \mathrm{C}$ (or $30^{\circ} \mathrm{C}$ in the case of L. pentosus strains) and streaked onto fresh plates every $24 \mathrm{~h}$. Plates were incubated at $37{ }^{\circ} \mathrm{C}$ or $30{ }^{\circ} \mathrm{C}$ under anaerobic conditions (AnaeroGen Atmosphere Generation system; Oxoid, United Kingdom) for 20-24 h prior to FISH experiments.

\subsection{PNA probe design}

To identify Lactobacillus genus potential targets for the probe design, we used the Primrose program (http://www.cf.ac.uk/biosi/ research/biosoft/Primrose/index.html; Ashelford et al., 2002) coupled with the 16S rRNA databases from the Ribosomal Database Project II (version 10.0; http://rdp.cme.msu.edu/; Cole et al., 2009). The complementarity to a lower number of non-target and to the higher number of target sequences were the main reasons for the PNA probe design.

The selected sequence was synthesized (Panagene, Daejeon, South Korea) and the oligonucleotide $\mathrm{N}$ terminus was attached to an Alexa Fluor 488 molecule via a double 8-amino-3,6-dioxaoctanoic acid
Table 1

Bacterial strains used in PNA-FISH assays in the present study. The PNA probe efficiency was tested in triplicate experiments for each strain, with the following qualitative evaluation: $(-)$ absent hybridization; $(+)$ poor hybridization; $(++)$ moderate hybridization; $(+++)$ good hybridization; and $(++++)$ optimal hybridization. The table shows the average value from the three experiments for each strain.

\begin{tabular}{|c|c|c|c|}
\hline Code & Species & Strain & $\begin{array}{l}\text { PNA probe } \\
\text { efficiency }\end{array}$ \\
\hline L1 & Lactobacillus (L.) pentosus & CECT4023 & ++++ \\
\hline $\mathrm{L} 2$ & L. casei & СЕСТ5275 & ++++ \\
\hline L3 & L. rhamnosus & СЕСТ288 & ++++ \\
\hline L4 & L. coryniformis sub. torquens & СЕСТ4129 & ++++ \\
\hline L5 & L. paracasei & CECT227 & ++++ \\
\hline L6 & L. acidophilus & ATCC4356 & ++++ \\
\hline L7 & L. agilis & CCUG 31450 & ++++ \\
\hline L8 & L. animalis & АТСС35046 & +++ \\
\hline L9 & L. bifermentans & АТСС35409 & +++ \\
\hline L10 & L. brevis & ATCC14869 & ++++ \\
\hline L11 & L. buchneri & ATCC4005 & +++ \\
\hline L12 & L. fermentum & ATCC11739 & +++ \\
\hline L13 & L. crispatus & АТCC 33820 & ++++ \\
\hline L14 & L. curvatus sub. Curvatus & ATCC25601 & ++++ \\
\hline L15 & L. delbrueckii sub. delbrueckii & АТCC9649 & +++ \\
\hline L16 & L. delbrueckii sub. Lactis & ATCC12315 & +++ \\
\hline L17 & L. farciminis & DSM20182 & ++++ \\
\hline L18 & L. fructivorans & ATCC8288 & +++ \\
\hline L19 & L. gallinarum & CCUG31412 & ++++ \\
\hline L20 & L. gasseri & ATCC9857 & ++++ \\
\hline L21 & L. graminis & DSM20719 & ++ \\
\hline L22 & L. hamster & ATCC43851T & +++ \\
\hline L23 & L. helveticus & ATCC15009 & ++++ \\
\hline L24 & L. hilgardii & NCFB962 & +++ \\
\hline L25 & L. intestinalis & ATCC49335 & +++ \\
\hline L26 & L. johnsonii & ATCC11506 & ++++ \\
\hline L27 & L. murinus & АТСС35020 & ++++ \\
\hline L28 & L. parabuchneri & ATCC12936 & ++++ \\
\hline L29 & L. paracasei sub. paracasei & CCUG27320 & +++ \\
\hline L30 & L. plantarum & NCIMB8827 & +++ \\
\hline L31 & L. reuteri & NCFB2656 & +++ \\
\hline L32 & L. rhamnosus & ATCC7469 & ++++ \\
\hline L33 & L. ruminis & ATCC27781 & ++++ \\
\hline L34 & L. sakei sub. carnosus & CCUG8045 & ++ \\
\hline L35 & L. salivarius & DEVRIESE94/438 & +++ \\
\hline L36 & L. plantarum & NCCB46043 & +++ \\
\hline E1 & Lactococcus lactis 53 & - & $-/++$ \\
\hline E2 & Streptococcus thermophilus A & - & - \\
\hline E3 & Streptococcus thermophilus B & - & $-/+++$ \\
\hline E4 & Leuconostoc mesenteroides & - & $-1+$ \\
\hline E5 & Bacillus subtilis & DSM 7-10 & - \\
\hline E6 & Enterococcus faecium & CECT410 & - \\
\hline E7 & Enterococcus faecalis & CECT184 & - \\
\hline E8 & Bacillus cereus & - & - \\
\hline E9 & Enterobacter aerogenes & CECT684 & - \\
\hline E10 & Salmonella enterica & - & - \\
\hline E11 & Escherichia coli 0157:H7 & NCTC12900 & - \\
\hline E12 & Staphylococcus aureus & СЕСТ976 & - \\
\hline E13 & Staphylococcus aureus & СЕСТ86 & - \\
\hline E14 & Shigella flexneri & ATCC12022 & - \\
\hline E15 & Listeria monocytogenes & - & - \\
\hline E16 & Klebsiella pneumoniae subsp. ozaenae & ATCC11296 & - \\
\hline E17 & Salmonella typhi & - & - \\
\hline E18 & Listeria seeligeri & СЕСТ917 & - \\
\hline E19 & Escherichia coli & СЕCT434 & - \\
\hline E20 & Listeria monocytogenes & СЕСТ5873 & - \\
\hline
\end{tabular}

(AEEA) linker (PNA Probe: Lac663, Alexa Fluor 488-00-ACATGGAG TTCCACT; HPLC purified $>90 \%$ ).

\subsection{Theoretical assessment of probe specificity and sensitivity}

In order to compare the performance of the PNA probe developed in the current study with that of other probes previously described (Table 2), their theoretical specificities and sensitivities were calculated according to Almeida et al. (2010), using updated databases available at the Ribosomal Database Project II (RDP II; http://rdp.cme.msu.edu/) through Primrose software and then confirmed by a BLAST search at 
the National Center for Biotechnology Information (http://www.ncbi. nlm.nih.gov/BLAST/). Only Lactobacillus strains with at least 1200 base pairs and good quality sequences were included. Briefly, theoretical sensitivity was calculated as $L S /(T L S) \times 100$, where $L s$ stands for the number of Lactobacillus strains detected by the probe and TLs for the total number of Lactobacillus strains present in the RDP II (http://rdp. cme.msu.edu/probematch/, last accession date, March 2012). Theoretical specificity was calculated as $n L s /(T n L) \times 100$, where $n L s$ stands for the number of non-Lactobacillus strains that did not react with the probe and $T n L$ for total of non-Lactobacillus strains examined.

\subsection{FISH protocol development}

Both hybridization procedures (in glass slides and in suspension) are able to detect and quantify potential probiotic lactobacilli. Moreover, glass slide hybridization is the more commonly used technique in analytical laboratories (Amann and Fuchs, 2008). While hybridization in suspension is usually used to avoid autofluorescence background in complex matrix samples (Almeida et al., 2009) and it is also the hybridization technique applied in flow cytometry (Amann et al., 1990; Amann and Fuchs, 2008).

\subsubsection{Hybridization procedure on glass slides and in suspension}

Protocols were developed both for hybridization on slides and in suspension. Even though the FISH protocols on slides and in suspension herein used are based on the previous work by Almeida et al. (2009, 2010), optimal fixation and hybridization conditions are crucial for a specific FISH method development. Therefore, these procedures were optimized considering the following modifications. Hybridization was done at $60{ }^{\circ} \mathrm{C}$ for $90 \mathrm{~min}$ and washing $\left(60{ }^{\circ} \mathrm{C}\right.$ for $30 \mathrm{~min}$ ) was prepared less than $24 \mathrm{~h}$ before use. The glass slides were allowed to air dry before microscopy visualization, while suspension samples were stored at $4{ }^{\circ} \mathrm{C}$ in the dark for a maximum of $24 \mathrm{~h}$ before microscopy visualization.

\subsubsection{Hybridization on milk samples}

All strains were grown on MRS or BHI plates, for 24-48 h (see Table 1). Afterwards, strains were suspended in distilled water and then homogenized by vortexing for $1 \mathrm{~min}$. Then, $1 \mathrm{ml}$ of cell suspension was pelleted by centrifugation at $10,000 \times \mathrm{g}$ for $5 \mathrm{~min}$, resuspended in $500 \mu \mathrm{l}$ of $4 \%$ (wt/vol) paraformaldehyde (Fisher Scientific, United Kingdom) and fixed for $1 \mathrm{~h}$. The fixed cells were washed in sterile water by centrifugation at $10,000 \times g$ for $5 \mathrm{~min}$, resuspended in $500 \mu \mathrm{l}$ of $50 \%$ (vol/vol) ethanol, and incubated for $30 \mathrm{~min}$ at $-20{ }^{\circ} \mathrm{C}$. Following this, a $100 \mu \mathrm{l}$ aliquot was pelleted by centrifugation, washed with sterile water and finally resuspended in $100 \mu \mathrm{l}$ of hybridization solution with 200 nM PNA probe. Next, the samples were incubated at identical hybridization time and temperature ranges as the ones referred above (see Section 2.4.1). Subsequent to the hybridization step, the sample was centrifuged again at $10,000 \times g$ for $5 \mathrm{~min}$, resuspended in $500 \mu \mathrm{l}$ of wash solution and then incubated for $30 \mathrm{~min}$ at the same temperature of the hybridization step. The washed suspension was pelleted by centrifugation and resuspended in $500 \mu \mathrm{l}$ of sterile water. The final step consisted of filtering $200 \mu \mathrm{l}$ of cell suspension through a $0.2 \mu \mathrm{m}$ cellulose nitrate membrane (Whatman, United Kingdom) or alternatively by spreading $20 \mu \mathrm{l}$ of the suspension on a microscope slide, allowing then the membrane or slide to air dry. After hybridization samples were stored at $4{ }^{\circ} \mathrm{C}$ in the dark for a maximum of $24 \mathrm{~h}$ before microscopy visualization.

\subsection{Microscopic visualization}

Before the microscopic evaluation, one drop of non-fluorescent immersion oil (Merck, Portugal) was added to either slides or filters and covered with coverslips. Microscopy visualization was performed using an Olympus BX51 (Olympus Portugal SA, Porto, Portugal) epifluorescence microscope equipped with one filter sensitive to the Alexa Fluor $488 \mathrm{~mol}-$ ecule attached to the PNA probe (BP 470-490), and an Olympus DP 72 camera. Other filters present in the microscope that are not capable of detecting the probe fluorescent signal were used to confirm the absence of autofluorescence (FT 500, LP 516). In each experimental assay, a negative control was performed simultaneously in which all the steps described above were carried out, but where no probe was added in the hybridization step. All images were acquired using Olympus CellB software using a magnification of $\times 1000$.

\subsection{Experimental assessment of probe specificity and sensitivity}

After the hybridization optimization, the specificity and sensitivity of the PNA probe were tested using 36 representative strains from Lactobacillus genus and 20 representative strains from related genera belonging to the Lactobacillales order (Kandler and Weiss, 1986; Hammes and Vogel, 1995) and common pathogens in food industry (see Table 1). Specifically, strains from the following genera were included: Lactococcus, Enterococcus, Leuconostoc, Streptococcus, Staphylococcus, Shigella, Listeria, Salmonella, Escherichia, Enterobacter, Bacillus and Klebsiella. All experiments were performed in triplicate at identical conditions and the experimental specificity and sensitivity were determined.

\subsection{PNA FISH validation against fresh milk samples}

For the direct detection of bacterial cells in milk, we selected a well-known probiotic and an uncommon probiotic Lactobacillus

Table 2

Theoretical specificity and sensitivity obtained for probes previously developed for the detection of Lactobacillus spp.

\begin{tabular}{|c|c|c|c|c|c|c|c|}
\hline Probe & Type & Sequence $\left(5^{\prime} 3^{\prime}\right)$ & $\begin{array}{l}\text { No. of Lactobacillus } \\
\text { strains detected }^{\text {a }}\end{array}$ & $\begin{array}{l}\text { No. of non-Lactobacillus } \\
\text { strains detected }^{\text {a }}\end{array}$ & Specificity (\%) & Sensibility (\%) & Reference or source \\
\hline Eub338 ${ }^{\mathrm{b}}$ & DNA & GCTGCCTCCCGTAGGAGT & 11,842 & 904,088 & 5.99 & 98.22 & Amann et al., 1990 \\
\hline Lab158 ${ }^{c}$ & DNA & GGTATTAGCA(C/T)CTGTTTCCA & 11,198 & 6,203 & 99.36 & 92.88 & Harmsen et al., 1999 \\
\hline LGC354A $^{\mathrm{d}}$ & DNA & TGGAAGATTCCCTACTGC & 11,852 & 11,585 & 98.80 & 98.30 & Meier et al., 1999 \\
\hline LAB759 & DNA & CTACCCATRCTTTCGAGCC & 10,371 & 2,823 & 99.72 & 80.17 & Zijnge et al., 2010 \\
\hline $\operatorname{LbpV}^{f}$ & DNA & CCGTCAATACCTGAACAG & 831 & 4 & 99.99 & 6.89 & Ercolini et al., 2003 \\
\hline $\begin{array}{l}\text { Name not } \\
\text { available }^{\mathrm{g}}\end{array}$ & PNA & GAATCTTCCACAATGG & 11,873 & 14,126 & 98.53 & 98.47 & Burton et al., 2003 \\
\hline Lact663 & PNA & ACATGGAGTTCCACT & 11,035 & 3,248 & 99.66 & 91.52 & This work \\
\hline
\end{tabular}

a Calculated through ProbeMatch/ (last accession, January 2012) with the following data set options: Strain-Both; Source-Both; Size->1200 bp; Quality-Both.

b DNA probe for Eubacteria being unspecific for Lactobacillus spp. but useful for comparative value.

c DNA probe also detects members of Enterococcus, Pediococcus, Weissella, Vagococcus, Leuconostoc and Oenococcus spp. used in Lebeer et al. (2011).

' DNA probe for mainly members of Lactobacillales and Bacillales, such as Lactobacillus spp., used in Olsen et al. (2008).

e DNA probe also detects members of Ruminococcaceae sp. and Pediococcus sp. used in Quevedo et al. (2011); the R symbol of the DNA probe sequence may be adenosine or guanosine, therefore Quevedo et al. (2011) used in fact two DNA probes to detect Lactobacillus spp.

${ }_{\mathrm{f}}$ DNA probe only hybridizes with certain strains Lactobacillus plantarum.

$g$ PNA probe for the detection of Lactobacillus-related genera. 
strain, more precisely, L. casei CECT 4023 (also known as ATCC 393; Sidira et al., 2010) and L. pentosus CECT 5275 (Lafarge et al., 2004; Zhu et al., 2007), respectively. These two strains were selected to demonstrate Lac663 capability for potential probiotic lactobacilli detection in complex matrix samples, such as milk samples. An inoculum of either Lactobacillus pentosus CECT 4023 or L. casei CECT 5275 was prepared in phosphate buffered saline (PBS) and, using a calibration curve of CFU vs O.D. (at a wavelength of $600 \mathrm{~nm}$ ), fresh milk (also known as raw milk) samples were inoculated with microbial concentrations ranging from $1 \times 10^{2}$ to $1 \times 10^{8} \mathrm{CFU} / \mathrm{ml}$. Also, we performed a spiked-milk inoculation with a mixture of Lactobacillus casei CECT 5275 and two non-Lactobacillus strains: Lactococcus lactis (E1) and Streptococcus thermophilus B (E3; Table 1). This spiked-milk sample was inoculated with a final concentration of $1 \times 10^{8} \mathrm{CFU} / \mathrm{ml}$ of each bacteria. Taking into account the previously reported detection limit of $2 \times 10^{5} \mathrm{CFU} / \mathrm{ml}$ for Cronobacter in powdered infant formula (Almeida et al., 2009), a simple and direct detection approach, after a ten-fold dilution (to avoid the interference of milk protein autofluorescence), was considered adequate to reach the desired detection limit. Therefore, all samples were diluted 1:10 and $1 \mathrm{ml}$ aliquots of each dilution were concentrated by centrifugation as described above. The fresh milk was previously pasteurized at $66{ }^{\circ} \mathrm{C}$ for $30 \mathrm{~min}$ (before FISH procedure) to reduce the naturally occurring microbial load from the initial lactobacilli or related bacterial strain inoculation in the milk samples. The pasteurization step was performed in our laboratory to ensure an efficient procedure and to maintain the same bacterial concentration from the initial inoculation, avoiding further proliferation of the bacteria in fresh milk samples through temperature inactivation. Hybridization was performed in suspension or on glass slides, then samples were visualized by epifluorescence microscope and concentration was determined by counting a total of 15 fields $(1000 \times)$ for each sample. Also, the samples were plated on MRS agar for CFU counts.

\section{Results and discussion}

\subsection{Theoretical assessment of probe specificity and sensitivity}

The sequence of the selected PNA probe is the shorter from all probes in Table 2, and it hybridizes between positions 663 and 677 of the Lactobacillus sp. strain MDL2 16S rRNA sequence (Genebank ID: HM753265.1), consequently it was denominated as Lac663. According to the consulted database of the RDP II Project, the Lac663 probe is fully complementary to 11,837 matches that correspond to target sequences. Since the Lactobacillus genus reveals 12,936 target sequences, the Lac663 probe theoretical sensitivity was found to be $91.52 \%$ (see Table 2). Considering a total of 1,018,924 nonLactobacillus sequences evaluated (isolates with good quality and sequence size $>1200 \mathrm{bp}$ ) from which 1,015,376 did not react with Lac663 probe, a theoretical specificity of $99.66 \%$ was determined.

These sensitivity and specificity equations allowed us to compare our Lac663 PNA probe with other probes that had previously been developed to detect and enumerate Lactobacillus spp. strains (Table 2). Lac663 theoretical performance was quite similar to what had previously been reported for the other probes mentioned in Table 2, except for Eub338 and LbpV3, which were designed for the detection of Eubacteria (Eub338) and Lactobacillus plantarum (LbpV3) and, as such, are not specific for the Lactobacillus genus. Although probes Lab158, LGC354A and the probe described by Burton et al. (2003) detected approximately 1 to $8 \%$ more Lactobacillus strains in comparison with our probe, Lac633 was found to be the probe with the lowest number of false positive hits (Table 2). In fact, the Lac663 probe does not cross-react with 3,617, 8,781 and 11,332 non-Lactobacillus strains that are detected with the Lab158, LGC354A and Burton et al. (2003) probes, respectively. Moreover, 5 of the 22 non-Lactobacillus genera detected by the Burton et al. (2003) PNA probe belong to the Carnobacteriaceae family and consequently to the LAB group (König and Fröhlich, 2009), more precisely, the following genera: Dolosigranulum; Atopostipes; Alloiococcus; Alkalibacterium; and Marinilactibacillus. This family of gram-positive, lactic acid-producing bacteria is used in several food applications, including probiotic milk and its products (Afzal et al., 2010; Bourdichon et al., 2012). A total of $51.95 \%$ of bacterial species from the Carnobacteriaceae family are detected by the Burton et al. (2003) PNA probe in contrast with only $0.34 \%$ detected by our probe. This demonstrates that the Lac663 probe shows a better specificity and applicability for analysis of fresh milk samples, which can be contaminated by a huge variety of bacteria. From Table 2 it can be concluded that only the LAB759 probe was more specific than the currently developed Lac663 probe. However, the LAB759 probe shows a clearly lower sensitivity percentage (80.17\%) compared to our probe $(91.52 \%)$. It is also important to note that our probe has the shortest oligonucleotide sequence from all the probes included in Table 2, more precisely 1 and 3 nucleotides less than the other PNA probe and the shorter DNA probe (LGC354A), respectively. This implies that the Lac663 probe should penetrate better through the cell wall and that 1 base mismatch can be more easily discriminated. Also, because it's a PNA based probe, it has higher resistance against enzymatic activity (such as DNases or proteases) from the bacterial cell, enabling superior FISH efficiency as previously discussed by Cerqueira et al. (2008).

In conclusion, our in silico analysis indicates that the Lac663 probe is able to induce hybridization more efficiently to Lactobacillus strains in complex samples than the other probes reported so far.

\subsection{FISH protocol development}

From the different temperatures and time periods tested, the best hybridization conditions were found to be $60{ }^{\circ} \mathrm{C}$ for $90 \mathrm{~min}$. Hybridization conditions revealed strong signal-to-noise ratio from $58{ }^{\circ} \mathrm{C}$ to $62{ }^{\circ} \mathrm{C}$, with incubation times ranging from 60 to $120 \mathrm{~min}$. As such, our FISH protocol can be performed within $3 \mathrm{~h}$, which constitutes a significant improvement as compared to previously described similar DNA probes by Lebeer et al. (2011) (Lab158 DNA probe with overnight hybridization of $12 \mathrm{~h}$ ). Also, as previously mentioned, all samples were visualized with other available filters and no autofluorescence was observed (see examples in Fig. 1). Specifically, the absence of autofluorescence in L14 and L34 pictures on red filter confirms the specificity of the Lac663 probe.

\subsection{Experimental assessment of probe specificity and sensitivity}

As expected by the in silico analysis, the Lac663 probe hybridized with all Lactobacillus collection strains whereas no hybridization was observed for the other species used, except for L. lactis 53, S. thermophilus $B$ and L. mesenteroides, which showed some cross-hybridization with the probe if a washing step of 15 min was used. To clarify these results we analyzed in silico 16S rRNA gene sequences from these three bacterial strains and we found only one mismatch at positions 670 for L. lactis (T) NCD0607T 16S rRNA gene sequence (RDPII ID: S000439498) and S. thermophilus (T) ATCC19258 16S rRNA gene sequence (RDPII ID: S000400852), more exactly a single medium-strength T/C mismatch. However, extending the washing step to 30 min and using fresh washing solution allowed the removal of the Lac663 probe poorly bound from all non-Lactobacillus strains with this single medium-strength $\mathrm{T} / \mathrm{C}$ mismatch in our bacteria culture collection. L. mesenteroides (T) NCFB529 (RDPII ID: S000003774) revealed a total common oligonucleotide sequence identical to Lactobacillus spp., which was already predicted in the theoretical evaluation and this actually occurs with all the probes developed for detection of Lactobacillus spp. described in Table 2. Despite of the cross-hybridization for this species, its coccus morphology allows differentiation from Lactobacillus spp., which have a rod-shaped morphology. Importantly, Lac663 probe 


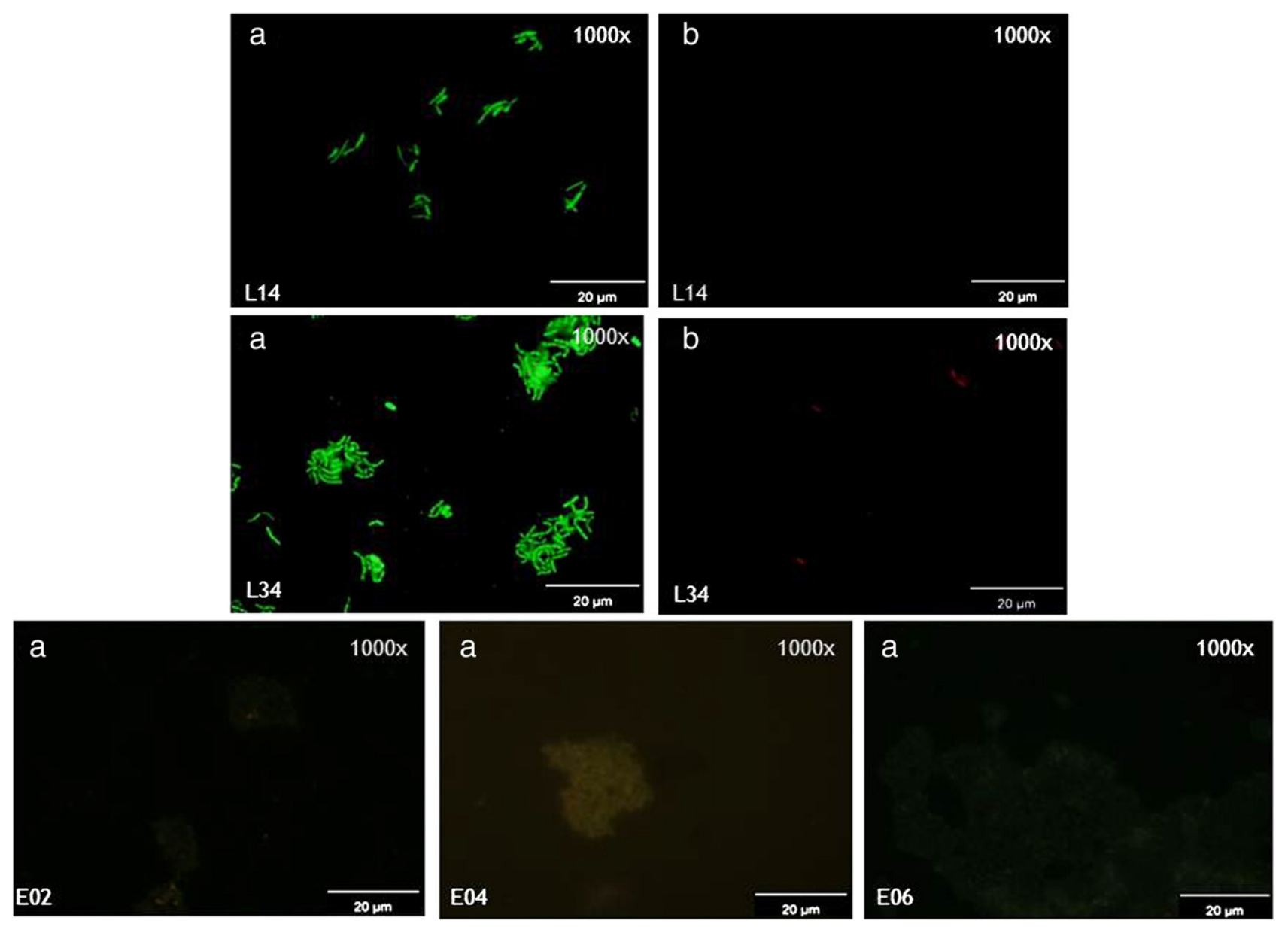

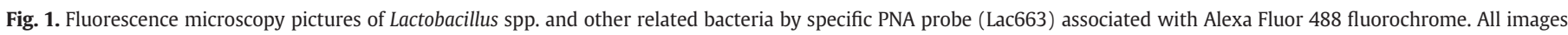

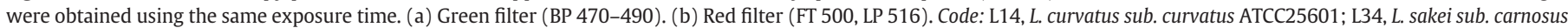
CCUG8045; E02, S. thermophilus A; E04, L. mesenteroides; E06, E. faecium.

showed an absence of hybridization with several bacterial species from the Bacilli class, such as $S$. thermophilus A, Enterococcus faecium CECT 410, Enterococcus faecalis CECT 184, Bacillus subtilis DSM 7-10 and Bacillus cereus. In addition, the probe also did not hybridize with several pathogenic bacteria which may contaminate industrial food such as Salmonella spp., Escherichia coli, Shigella spp. and Listeria monocytogenes. Therefore, these results support the advantages previously mentioned about the reliable application of PNA probes in FISH methodology and corroborates the theoretical prediction. Based on this test, experimental sensitivity of $100 \%$ (95\% confidence interval (CI), 88.0 to $100.0 \%$ ) and specificity of 95.0\% (95\% CI, 73.1 to $99.7 \%$ ) were obtained.

\subsection{PNA FISH validation against fresh milk samples}

After the optimization of the Lac663 FISH protocol the method was adapted for the detection and quantification of Lactobacillus spp. in a milk sample enriched with probiotic strains. According to Ishibashi and Shimamura (1993), we have defined a desired detection limit of $1 \times 10^{7} \mathrm{CFU} / \mathrm{ml}$. As expected, after hybridization with the Lac663 probe, microscopic visualization showed that Lactobacillus species could be detected up to the concentration of $1 \times 10^{7} \mathrm{CFU} / \mathrm{ml}$ (Fig. 2 and Table 3). The concentration of inoculated bacteria in the fresh milk samples was determined by conventional plating techniques (as CFU/ml) and by PNA FISH counts (as cell/ml; Table 3). As expected, PNA FISH counts were higher than CFU, which most probably was due to the presence of non-cultivable cells. Furthermore, we performed a spiked-milk experiment with a mixture of $L$. casei CECT
5275 and the two previously mentioned non-Lactobacillus strains with one single medium G/T mismatch, more exactly, L. lactis (E1) and S. thermophilus B (E3; Table 1). The aim of this experiment was to confirm that Lac663 probe only hybridized to the Lactobacillus genus using a washing step of $30 \mathrm{~min}$. No unspecific hybridization was observed in the spiked milk sample hybridization (data not shown), thus confirming Lac663 probe applicability in the detection and quantification of Lactobacillus species in complex samples.

Epifluorescence microscopy has become a widely used technique for direct estimation of bacteria in several industrial samples. In fact, many authors demonstrated the efficiency of FISH methodology in lactobacilli analysis (Bernardeau et al., 2001; Lebeer et al., 2011; Matte-Taillez et al., 2001); however none of them achieved the simplicity and specificity that our method offers. For example, Bernardeau et al. (2001) successfully performed a quantitative analysis of lactobacilli in probiotic feed, but lactobacilli were counted by an unspecific fluorochrome (DAPI-4', 6-diaminidino-2-phenylindole-2HCL). Matte-Taillez et al. (2001) also used DNA and PNA FISH methodology for the detection and identification of lactic acid bacteria on milk samples. However, these authors had to apply multiple PNA probes for lactobacilli identification, which makes the analysis more expensive and complex.

Regarding the traditional culture method for enumeration of Lactobacillus spp., it takes at least $48 \mathrm{~h}$, even with a more advanced Petrifilm ${ }^{\mathrm{TM}}$ AC system used by Champagne et al. (2009). Similar results were obtained by Jackson et al. (2002), who used two selective media for the detection and enumeration of lactobacilli followed by a PCR for lactobacilli confirmation. 

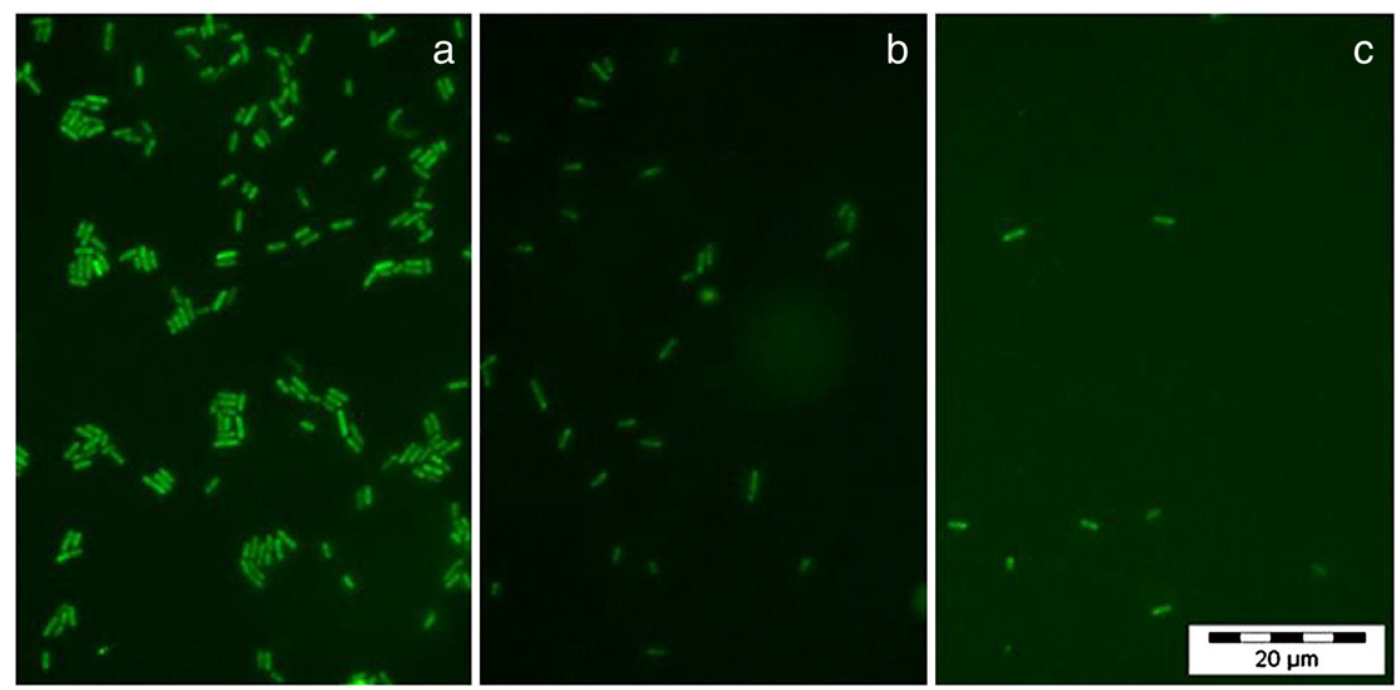

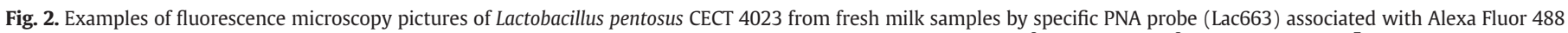
fluorochrome. Total cell counting determined for fresh milk samples with different initial concentrations, such as $10^{9} \mathrm{CFU} / \mathrm{ml}(\mathrm{a}), 10^{8} \mathrm{CFU} / \mathrm{ml}$ (b) and $10^{7} \mathrm{CFU} / \mathrm{ml}$ (c).

As regards to molecular methods other than FISH, Collado and Hernández (2007) used an Amplified Ribosomal DNA Restriction Analysis (ARDRA) and a Randomly Amplified Polymorphic DNA (RAPD) method that allowed discrimination of lactobacilli from other bacteria present on milk samples, but both techniques involved a much more complex protocol and were not capable of enumerating lactobacilli in the samples. Quantitative Real-Time PCR (qPCR) methods, which allow a quantitative detection, have been developed by Haarman and Knol (2006). qPCR methods can be performed at the same time as the FISH methodology; however they might also suffer from the presence of inhibitory substances in food samples, such as the other PCR techniques.

In summary, the Lactobacillus genus is present in probiotic milk and other-related products, such as cheese and yogurts. Quality assurance of the health or technological benefits of these products requires a fast detection and quantification of these bacteria.

The Lac663 probe was found to be a specific and sensitive PNA probe for Lactobacillus spp. that together with FISH methodology may be a reliable and fast (approximately $3 \mathrm{~h}$ ) alternative technique for potential probiotic lactobacilli detection and/or quantification in complex matrices, such as the probiotic milk samples. Using this method, only milk samples with an effective number of probiotic bacteria (at least $10^{7} \mathrm{CFU} / \mathrm{ml}$ ) will show appropriate results. However, if a lower detection limit is desired, a destabilizing solution may be applied to the milk samples followed by a filtration step, to concentrate the samples.

Further studies are necessary to determine if the Lac663 probe validated here for milk samples, is also useful for other applications such as the detection and enumeration of Lactobacillus spp. in feed probiotic samples. It might also be combined with other PNA probes in multiplex assays, thus allowing the simultaneous detection and quantification of other bacterial species.

\section{Acknowledgements}

This work was supported by European Union funds (FEDER/ COMPETE) and by national funds (FCT) under the project with reference FCOMP-01-0124-FEDER-008991 (PTDC/BIA-MIC/098228/ 2008. Antonio Machado acknowledges the FCT individual fellowshipSFRH/BD/62375/2009. However, it is important to refer that FCT did not have any role in the design of the experiments or manuscript writing.

\section{References}

Afzal, M., Jacquet, T., Delaunay, S., Borges, F., Millière, J., Revol-Junelles, A., Cailliez-Grimal, C., 2010. Carnobacterium maltaromaticum: identification, isolation tools, ecology and technological aspects in dairy products. Food Microbiology 27, 573-579.

Almeida, C., Azevedo, N.F., Iversen, C., Fanning, S., Keevil, C., Vieira, M.J., 2009. Development and application of a novel peptide nucleic acid probe for the specific detection of Cronobacter genomospecies (Enterobacter sakazakii) in powdered infant formula. Applied and Environmental Microbiology 75, 2925-2930.

Almeida, C., Azevedo, N.F., Fernandes, R., Keevil, C., Vieira, M.J., 2010. A fluorescence in situ hybridization method using a peptide nucleic acid probe for the identification of Salmonella spp. in a broad spectrum of samples. Applied and Environmental Microbiology 76, 4476-4485.

Amann, R., Fuchs, B., 2008. Single-cell identification in microbial communities by improved fluorescence in situ hybridization techniques. Nature Reviews. Microbiology 6, 339-348.

Amann, R., Binder, B., Olson, R., Chisholm, S., Devereux, R., Stahl, D., 1990. Combination of 16S rRNA-targeted oligonucleotide probes with flow cytometry for analyzing mixed microbial populations. Applied and Environmental Microbiology 56, 1919-1925.

Ashelford, K., Weightman, A., Fry, J., 2002. PRIMROSE: a computer program for generating and estimating the phylogenetic range of 16S rRNA oligonucleotide probes and primers in conjunction with the RDP-II database. Nucleic Acids Research 30, 3481-3489.

Bernardeau, M., Vernoux, J., Gueguen, M., 2001. Usefulness of epifluorescence for quantitative analysis of lactobacilli in probiotic feed. Applied and Environmental Microbiology 91, 1103-1109.

Table 3

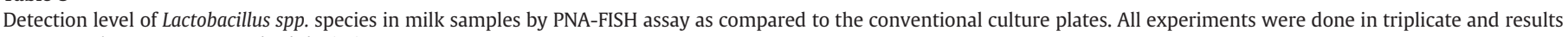
represent the average \pm standard deviation.

\begin{tabular}{|c|c|c|c|c|}
\hline \multirow{2}{*}{$\begin{array}{l}\text { Concentration of cells } \\
(\mathrm{CFU} / \mathrm{ml})\end{array}$} & \multicolumn{2}{|l|}{ L. pentosus CECT4023 } & \multicolumn{2}{|l|}{ L. casei CECT5275 } \\
\hline & Culturable cells (CFU/ml) & FISH count (cells/ml) & Culturable cells (CFU/ml) & FISH count (cells/ml) \\
\hline $1 \times 10^{8}$ & $7.00 \times 10^{7} \pm 1.96$ & $2.14 \times 10^{8} \pm 0.24$ & $4.50 \times 10^{7} \pm 0.83$ & $2.59 \times 10^{8} \pm 0.09$ \\
\hline $1 \times 10^{7}$ & $6.54 \times 10^{6} \pm 2.73$ & $6.97 \times 10^{7} \pm 1.87$ & $3.76 \times 10^{6} \pm 0.20$ & $8.32 \times 10^{7} \pm 2.29$ \\
\hline $1 \times 10^{6}$ & $7.43 \times 10^{5} \pm 1.84$ & - & $4.48 \times 10^{5} \pm 1.75$ & - \\
\hline $1 \times 10^{5}$ & $7.56 \times 10^{4} \pm 1.79$ & - & $4.89 \times 10^{4} \pm 2.45$ & - \\
\hline $1 \times 10^{4}$ & $1.08 \times 10^{4} \pm 0.61$ & - & $5.34 \times 10^{3} \pm 2.59$ & - \\
\hline $1 \times 10^{3}$ & $6.99 \times 10^{2} \pm 0.74$ & - & $9.44 \times 10^{2} \pm 6.52$ & - \\
\hline
\end{tabular}


Bernardeau, M., Vernoux, J., Henri-Dubernet, S., Guéguen, M., 2008. Safety assessment of dairy microorganisms: the Lactobacillus genus. International Journal of Food Microbiology 126, 278-285.

Bottari, B., Santarelli, M., Neviani, E., Gatti, M., 2010. Natural whey starter for Parmigiano Reggiano: culture-independent approach. Journal of Applied Microbiology 108, 1676-1684.

Bourdichon, F., Casaregola, S., Farrokh, C., Frisvad, J., Gerds, M., Hammes, W., Harnett, J., Huys, G., Laulund, S., Ouwehand, A., Powell, I., Prajapati, J., Seto, Y., Schure, E., Boven, A., Vankerckhoven, V., Zgoda, A., Tuijtelaars, S., Hansen, E., 2012. Food fermentations: microorganisms with technological beneficial use. International Journal of Food Microbiology 154, 87-97.

Burton, J., McCormick, J., Cadieux, P., Reid, G., 2003. Digoxigenin-labelled peptide nucleic acid to detect lactobacilli PCR amplicons immobilized on membranes from denaturing gradient gel electrophoresis. Letters in Applied Microbiology 36, 145-149.

Cerqueira, L., Azevedo, N.F., Almeida, C., Jardim, T., Keevil, C., Vieira, M.J., 2008. DNA mimics for the rapid identification of microorganisms by fluorescence in situ hybridization (FISH). International Journal of Molecular Sciences 9, 1944-1960.

Champagne, C., Raymond, Y., Gonthier, J., Audet, P., 2009. Enumeration of the contaminating bacterial microbiota in unfermented pasteurized milks enriched with probiotic bacteria. Canadian Journal of Microbiology 55, 410-418.

Cole, J., Wang, Q., Cardenas, E., Fish, J., Chai, B., Farris, R., Kulam-Syed-Mohideen, A., McGarrell, D., Marsh, T., Garrity, G., Tiedje, J., 2009. The Ribosomal Database Project: improved alignments and new tools for rRNA analysis. Nucleic Acids Research $37,141-145$

Collado, M., Hernández, M., 2007. Identification and differentiation of Lactobacillus, Streptococcus and Bifidobacterium species in fermented milk products with bifidobacteria. Microbiological Research 162, 86-92.

Ercolini, D., Hill, P., Dodd, C., 2003. Bacterial community structure and location in Stilton cheese. Applied and Environmental Microbiology 69, 3540-3548.

FAO/WHO, 2006. Evaluation of health and nutritional properties of probiotics in food including powder milk with live lactic acid bacteria. Report of a Joint FAO/WHO Expert Consultation. (http://ftp.fao.org/docrep/fao/009/a0512e/a0512e00.pdf. Accessed 26 January 2012)

Farnworth, E., 2008. The evidence to support health claims for probiotics. The Journal of Nutrition 138, 1250S-1254S

Gaurner, F., Khan, A., Garisch, J., Eliakim, R., Gangl, A., Thomson, A., Krabshuis, J., Mair, T., 2008. Probiotics and prebiotics. World Gastroenterology Organisation Practice Guidelines. (http://www.worldgastroenterology.org/probiotics-prebiotics.html. Accessed 26 January 2012).

Giraffa, G., Chanishvili, N., Widyastuti, Y., 2010. Importance of lactobacilli in food and feed biotechnology. Research in Microbiology 161, 480-487.

Guimaraes, N., Azevedo, N.F., Figueiredo, C., Keevil, C., Vieira, M.J., 2007. Development and application of a novel peptide nucleic acid probe for the specific detection of Helicobacter pylori in gastric biopsy specimens. Journal of Clinical Microbiology 45, 3089-3094.

Haarman, M., Knol, J., 2006. Quantitative real-time PCR analysis of fecal Lactobacillus species in infants receiving a prebiotic infant formula. Applied and Environmental Microbiology 72, 2359-2365

Hammes, W. Vogel, R., 1995. The genus Lactobacillus. In: Wood, B.J., Holzapfel, W.H. (Eds.), The Genera of Lactic Acid Bacteria, vol. 2, Blackie Academic and Professional, London, United Kingdom, pp. 19-54.

Harmsen, H., Elfferich, P., Schut, F., Welling, G., 1999. A 16S rRNA-targeted probe for detection of lactobacilli and enterococci in faecal samples by fluorescent in situ hybridization. Microbial Ecology in Health and Disease 11, 3-12.

Ishibashi, N., Shimamura, S., 1993. Bifidobacteria: research and development in Japan. Food Technology 47, 126-135.

Jackson, M., Bird, A., McOrist, A., 2002. Comparison of two selective media for the detection and enumeration of Lactobacilli in human feces. Journal of Microbiological Methods 51, 313-321.

Justé, A., Thommad, B., Lievens, B., 2008. Recent advances in molecular techniques to study microbial communities in food-associated matrices and processes. Food Microbiology 25, 745-761.

Kandler, O., Weiss, N., 1986. Genus Lactobacillus. In: Sneath, P.H., Mair, N.S., Sharpe, N.E., Holt, J.H. (Eds.), Bergey's Manual of Systematic Bacteriology. Williams and Wilkins, Baltimore, pp. 1209-1234.

Kaufmann, P., Pfefferkorn, A., Teuber, M., Meile, L., 1997. Identification and quantification of Bifidobacterium species isolated from food with genus specific 16S rRNA-targeted probes by colony hybridization and PCR. Applied and Environmental Microbiology $63,1268-1273$.

König, H., Fröhlich, J., 2009. Lactic acid bacteria, In: König, H. (Ed.), Biology of Microorganisms on Grapes, in Must and in Wine, third ed. Springer-Verlag, Berlin Heidelberg, pp. 1-5.
Lafarge, V., Ogier, J., Girard, V., Maladen, V., Leveau, J., Gruss, A., Delacroix-Buchet, A 2004. Raw cow milk bacterial population shifts attributable to refrigeration. Applied and Environmental Microbiology 70, 5644-5650.

Lahtinen, S., Gueimonde, M., Ouwehand, A., Reinikainen, J., Salminen, S., 2005. Probiotic bacteria may become dormant during storage. Applied and Environmental Microbiology 71, 1662-1663.

Langer-Safer, P.R., Levine, M., Ward, D.C., 1982. Immunological method for mapping genes on Drosophila polytene chromosomes. Proceedings of the National Academy of Sciences 79, 4381-4385.

Lebeer, S., Verhoeven, T., Claes, I., De Hertogh, G., Vermeire, S., Buyse, J., Van Immerseel, F. Vanderleyden, J., De Keersmaecker, S., 2011. FISH analysis of Lactobacillus biofilms in the gastrointestinal tract of different hosts. Letters in Applied Microbiology 52, $220-226$.

Lourens-Hattingh, A., Viljoen, B., 2002. Survival of probiotic bacteria in South African commercial bioyogurt. South African Journal of Science 98, 298-300.

Matsumoto, K., Takada, T., Shimizu, K., Kado, Y., Kawakami, K., Makino, I., Yamaoka, Y., Hirano, K., Nishimura, A., Kajimoto, O., Nomoto, K., 2006. The effects of a probiotic milk product containing Lactobacillus casei strain Shirota on the defecation frequency and the intestinal microflora of sub-optimal health state volunteers: a randomized placebo-controlled cross-over study. Bioscience and Microflora 25, 39-48.

Matte-Taillez, O., Quénée, P., Çibik, R., Van Opstal, J., Dessevre, F., Firmesse, O., Tailliez, P., 2001. Detection and identification of lactic acid bacteria in milk and industria starter culture with fluorescently labeled rRNA-targeted peptide nucleic acid probes. Le Lait 81, 237-248.

Meier, H., Amann, R., Ludwig, W., Schleifer, K., 1999. Specific oligonucleotide probes for in situ detection of a major group of gram-positive bacteria with low DNA G + C content. Systematic and Applied Microbiology 22, 186-196.

Mothershed, E., Whitney, A., 2006. Nucleic acid-based methods for the detection of bacterial pathogens: present and future considerations for the clinical laboratory. Clinica Chimica Acta 363, 206-220.

Olsen, K., Henriksen, M., Bisgaard, M., Nielsen, O., Christensen, H., 2008. Investigation of chicken intestinal bacterial communities by 16S rRNA targeted fluorescence in situ hybridization. Antonie Van Leeuwenhoek 94, 423-437.

Quevedo, B., Giertsen, E., Zijnge, V., Lüthi-Schaller, H., Guggenheim, B., Thurnheer, T., Gmür, R., 2011. Phylogenetic group- and species specific oligonucleotide probes for single-cell detection of lactic acid bacteria in oral biofilms. BMC Microbiology 11, 14. http://dx.doi.org/10.1186/1471-2180-11-14

Satokari, R., Vaughan, E., Smidt, H., Saarela, M., Mättö, J., de Vos, W., 2003. Molecular approaches for the detection and identification of bifidobacteria and lactobacilli in the human gastrointestinal tract. Systematic and Applied Microbiology 26, 572-584

Saxelin, M., Tynkkynen, S., Mattila-Sandholm, T., de Vos, W., 2005. Probiotic and other functional microbes: from markets to mechanisms. Current Opinion in Biotechnology $16,204-211$.

Shah, N.P., Lankaputhra, W.E., 1997. Improving viability of Lactobacillus acidophilus and Bijidobacterium spp. in yogurt. International Dairy Journal 7, 349-356.

Sidira, M., Galanis, A., Ypsilantis, P., Karapetsas, A., Progaki, Z., Simopoulos, C., Kourkoutas, Y 2010. Effect of probiotic-fermented milk administration on gastrointestinal survival of Lactobacillus casei ATCC 393 and modulation of intestinal microbial flora. Journal of Molecular Microbiology and Biotechnology 19, 224-230.

Sohier, D., Lonvaud-Funel, A., 1998. Rapid and sensitive in situ hybridization method for detecting and identifying lactic acid bacteria in wine. Food Microbiology 15, 391-397.

Spiegelman, D., Whissell, G., Greer, C., 2005. A survey of the methods for the characterization of microbial consortia and communities. Canadian Journal of Microbiology $51,355-386$.

Stender, H., Fiandaca, M., Hyldig-Nielsen, J., Coull, J., 2002. PNA for rapid microbiology. Journal of Microbiological Methods 48, 1-17.

Tabasco, R., Paarup, T., Janer, C., Pelaez, C., Requena, T., 2007. Selective enumeration and identification of mixed cultures of Streptococcus thermophilus, Lactobacillus delbrueckii subsp bulgaricus, $L$ acidophilus, $L$ paracasei subsp. paracasei and Bifidobacterium lactis in fermented milk. International Dairy Journal 17, 1107-1114.

Zhu, Y., Lee, Y., Elander, R., 2007. Conversion of aqueous ammonia-treated corn stover to lactic acid by simultaneous saccharification and cofermentation. Applied Biochemistry and Biotechnology 140, 721-738.

Zijnge, V., van Leeuwen, M., Degener, J., Abbas, F., Thurnheer, T., Gmür, R., Harmsen, H. 2010. Oral biofilm architecture on natural teeth. PLoS One 5, e9321. http:// dx.doi.org/10.1371/journal.pone.0009321. 